ANDRZEJ STĘPNIK (Lublin)

\title{
MIĘDZY TEORIĄ A PRAKTYKĄ. DYLEMATY REGIONALISTYKI HISTORYCZNEJ W II RZECZYPOSPOLITEJ
}

Zainteresowania historią regionalną są tak stare jak sama historia. Ludzie zawsze, $z$ różnych względów, wy kazywali tendencję do wyróżniania swej „mniejszej ojczyzny”. Głębsza refleksja nie towarzyszyła temu jednak aż do XIX stulecia, kiedy to we Francji pojawił się ruch społeczno-kulturalny, dążący do zachowania i pogłębienia swoistych cech kultury danego obszaru. Nazwano go wówczas regionalizmem, który szybko utorował sobie drogę do różnych dziedzin kultury i oświaty. W Polsce ruch ten znalazł uznanie szczególnie w okresie międzywojennym.

Odzyskanie niepodległości przez Polskę w r. 1918 odmieniło bowiem potrzeby społeczne i warunki życia w państwie. Patriotyzm, manifestowany dotychczas często językiem symboli, zaczął wyrażać się przede wszystkim postawą aktywności i pracą na rzecz lokalnej społeczności. Wielkie problemy życia narodowego przeniosły się w teren, przyczyniając się do awansu kulturalnego prowincji. „Regionalność”, dotychczas często będąca koniecznością, stała się atrybutem nowej polskiej rzeczywistości. Dziewiętnastowieczne zapotrzebowanie na syntezy dziejów ojczystych zastąpiło oczekiwanie na opracowania historyczno-regionalne. Zjawisko to wynikało $z$ potrzeby poszukiwania przez lokalne społeczności swego historycznego rodowodu, własnego miejsca w wielkich procesach dziejowych, potwierdzenia swego współuczestnictwa w budowaniu nowej Polski. Wiązało się także $z$ demokratyzacją życia w odrodzonym państwie.

Historycy polscy okresu międzywojennego zaczęli mówić o historii regionalnej i lokalnej jako specyficznej gałęzi badań czy popularyzacji. Dla niektórych badaczy była ona nawet odrębną dziedziną nauki historycz- 
$n^{1}{ }^{1}$. Nie powstała jednak wówczas spójna', akceptowana przez wszystkich (lub większość) historyków teoria historii regionalnej (lokalnej). Dziedzina ta podlegała w latach 1918-1939 oddziaływaniu wielu czynników, które zadecydowały w konsekwencji o ogromnej różnorodności powstałych w jej ramach prac. Spośród ważniejszych wymieńmy tu związki z szeroko rozumianym ruchem regionalistycznym, społeczno-politycznymi i kulturalnymi potrzebami odrodzonego państwa, wewnętrznymi przemianami zachodzącymi w polskiej historiografii, nie wspominając już o sprawach dość oczywistych, jakimi były potrzeby zaspokajania swych potrzeb intelektualnych przez poszczególne środowiska lokalne ${ }^{2}$.

Szersze lub węższe wypowiedzi (częściej wzmianki) na temat regionalizmu historycznego można znaleźć w wystąpieniach niemal wszystkich historyków okresu międzywojennego. Łączyła je pewna wspólna płaszczyzna myślowa: historia regionalna i lokalna ma na celu badanie i popularyzowanie przeszłości terytoriów mniejszych niż państwo. W kwestiach szczegółowych o wiele trudniej pokazać to, co integrowało niż dzieliło poszczególnych historyków. Najczęściej bowiem pojęcie to było używane w sposób intuicyjny, nie kryły się za nim solidniejsze przemyślenia naukowe. Wszystko to zdecydowało w dużej mierze o zróżnicowanej kondycji regionalistyki w II Rzeczypospolitej.

W okresie międzywojnia zarysowały się dwa główne środowiska, które w charakterystyczny dla siebie sposób podchodziły do kwestii rozumienia istoty historii regionalnej i lokalnej. Pierwsze z nich grupowało przedstawicieli tzw. ruchu regionalistycznego, drugie zaś ludzi wysuwających na plan pierwszy potrzeby nauki.

Najmniejsze relatywnie niepokoje związane z poznawaniem dziejów swej „mniejszej ojczyzny” przeżywali dziejopisarze związani z programem polskiego ruchu régionalistycznego ${ }^{3}$. Utożsamiali się oni z celami europejskiego

1 Por. S. Krakowski, Problematyka miejska w historiografii polskiej. Informacje bibliograficzne, metodologia, zagadnienia (ze szczególnym uwzględnieniem okresu 19291949), druk powielany, Eódź 1950, s. 5.

2 Rangę ostatniego $\mathrm{z}$ wymienionych czynników w rozwoju historiografii regionalnej akcentują m.in. H. Samsonowicz, Historiografia regionalna w Polsce po II wojnie światowej, „Kwartalnik Historyczny”, r. 94, $1987 \mathrm{nr}$ 1, s. 284; Z. Mańkowski, Historiografia regionalna $w$ Polsce. (Przeglqd zagadnienia), w: O regionálnich déjinách. Materiály $z$ konference Kabinetu Regionálnich Déjin pri Katedre Historie Filozofické Fakulty Univerzity Pálackého v Olomouci. Rożnov pod Radhoštém 21-23 února 1979, Olomouc 1980, s. $30-43$.

3 Por. Program regionalizmu polskiego, „Ziemia”, r. 11, 1926 nr 13/14, s. 211-212; toż: „Życie Podlasia”, r. 3, 1926 n r 24, s. 1-2; toż. „Kronika Miasta Poznania”, r. 4, 1926 
prądu społeczno-kulturalnego, dążącego do „zachowania swoistych cech kultury danego obszaru, do pogłębienia wiedzy o tej kulturze, do jej rozwoju i odnowy" ". Istota historii regionalnej była dla nich pochodną dążeń tegoż ruchu. Regionaliści nigdy nie definiowali ściśle powyższego pojęcia. Oznaczało ono dla nich tak opis dziejów wsi i miasteczek, jak i dużych, historycznych prowincji państwa. Aby wyłowić jego sens, musimy odwołać się do bardziej charakterystycznych wypowiedzi przedstawicieli tego ruchu, zrodzonego w dziewiętnastowiecznej Francji ${ }^{5}$.

Teoretycznym uzasadnieniem ich działalności była swojego rodzaju filozofia, akceptowana - co należy podkreślić - prawie przez wszystkich regionalistów. Zakładała ona, najkrócej rzecz biorąc, że w każdych warunkach i na każdym miejscu istnieje ścisły związek pomiędzy życiem ludzkim a jego otoczeniem. Struktury te - sądzono - nawzajem się przenikają i uzupełniają w nieskończenie różnych formach. Kiedy większość ich elementów znajdzie się w stanie równowagi, wówczas możliwe staje się ujawnienie ludzkich wartości, warunkujących harmonijne współżycie i twórczą pracę. Za podstawę osiągnięcia takiego ładu regionaliści uważali utrwalenie najlepszych tradycji historycznych ustalonych na określonym terytorium prawami natury. Ideolodzy regionalizmu przyznawali sobie prawo wyboru z przeszłości tego co „żywe” i odrzucenie tego co „martwe”. Postawa ta odcisnęła wyraźne piętno na pracach historyczno-regionalnych powstałych w tym kręgu.

Historia - jak z powyższego wynika - zajmowała szczególne miejsce w ruchu regionalistycznym. Jego twórcy, opierając swą ideologię na ukształtowanej przez warunki dziejowe odrębności kulturowej poszczególnych dzielnic kraju, traktowali ją jako środek do rozpoznawania i rozwiązywania wielu problemów nurtujących państwo i społeczności lokalne.

Konsekwencją takiej postawy było inspirowanie rozlicznych działań obejmu jących badania, popularyzację i nauczanie dziejów regionalnych i lokalnych. Sprzyjało temu przekonanie o łatwości poznawania przeszłości najbliższej okolicy z uwagi na powszechność dostępu do źródeł i rzekomo niskie

nr 10, s. 220-223; o recepcji programu regionalistycznego w społeczeństwie polskim pisali m.in. W. Kołodziej, Z. Żiżka, Ruch regionalistyczny w Polsce dawniej $i$ dziś, "Zeszyty Historyczno-Polityczne Stronnictwa Demokratycznego" 1986, z. 2, s. 62-73.

4 Cyt. za Stownik języka polskiego, red. M. Szymczak, t. 3, Warszawa 1981, s. 34-35; por. też S. Annold, Stowo wstępne, w: A. Patkowski, Whotdzie ziemi rodzinnej, Warszawa 1958 , s. 5.

5 Ch. Brun, Regionalizm francuski, w: Ruch regionalistyczny $w$ Europie, praca zbiorowa, red. A. Patkowski, Warszawa 1934, s. 267. 
koszty badań historycznych ${ }^{6}$. Zjawisko to, niezwykle złożone w swojej istocie, można określić mianem regionalizmu historycznego. Traktować go należy jako jedną z odmian regionalizmu w sensie ogólnym, który przeniknął niemal do wszystkich dziedzin kultury. Analogicznie moglibyśmy więc mówić o regionalizmie literackim, muzycznym, teatralnym itp., choć wszystkie w większym lub mniejszym stopniu nawiązywały do historii.

Ruch regionalistyczny w Polsce znalazł dobre warunki rozwoju, gdyż tu - jak napisał Zygmunt Mańkowski - „złożoność procesu historycznego, przemieszczające się wpływy Wschodu i Zachodu (swoiste pogranicze), rozbicie dzielnicowe, zabory, nierówne tempo rozwoju ekonomicznego kraju itp. [...] doprowadziły do daleko posuniętej specyfiki kraju (a nawet jego regionów, subregionów itp.)" ?. Zarówno w okresie zaborów jak i Polski Odrodzonej wspólny rodowód kulturowy poszczególnych terenów oraz poczucie pewnej subtelnej odrębności psychicznej, wynikającej z faktu zamieszkiwania danej jednostki terytorialno-ludnościowej, był czynnikiem integrującym poszczególne środowiska i rodzącym wiele oddolnych, autentycznych inicjatyw społecznych. Regionalne zainteresowania historią uchodziły zaś za miernik poziomu kulturalnego lokalnych, zwłaszcza małomiasteczkowych, społeczności.

Ruch regionalistyczny i jego ideologia objęły wiele sfer i płaszczyzn ludzkiej aktywności i w poważnym stopniu wpłynęły na rozwój zainteresowań historyczno-regionalnych. Oddziaływały szczególnie na środowiska w zasadzie pozbawione tradycji naukowych, świat nauczycielski oraz działaczy związanych $z$ ruchem krajoznawczym i samorządowym. Historia miała tu głównie pełnić rolę katalizatora w procesie awansu cywilizacyjnego prowincji.

Twórczość autorów programowo związanych z ideologią regionalistyczną - z racji ich stosunku do historii - dawała w efekcie uproszczony (czasem wręcz nieprawdziwy) obraz dziejów. Nie towarzyszyła im zwykle głębsza refleksja teoretyczna. Historię tę wszakże najczęściej uprawiali amatorzy i półprofesjonaliści. Traktowali ją jako formę działalṇości społecznej, drogę do osiągnięcia pewnych celów utylitarnych, przynoszących pożytek swej „mniejszej ojczyźnie”, lub „potrzebę serca”. Pod względem warsztatu próbowali po prostu naśladować dawnych dziejopisów (głównie dziewiętnastowiecznych). Widać to nawet w tytułach publikacji tego okresu ${ }^{8}$. W opracowaniach po-

6 Por. np. T. Dobrowolski, Życie naukowe Ślqska, „Nauka Polska”, t. 19, 1934, s. 334.

7 Z. Mańkowski, op. cit., s. 30.

8 Np. J. Majewski, Euków m. powiatowe w województwie lubelskim. Dawnych dziejów i doby wspótczesnej szkic krótki, „Gazeta Łukowska” 1924, nr 5, s. 3. 
wstałych w tym kręgu zaznaczyła się wyraźnie tendencja do wykorzystywania wszystkich znanych danemu autorowi faktów i traktowania dostępnych źródeł w sposób jednakowo poważny. Wymóg selekcji był niemal programowo odrzucany. Prowadziło to często do nieprzewidzianych konsekwencji. Obserwować to możemy między innymi w pracy polskiego patrioty Stanisława Dołęgi o dziejach Torunia w dobie nowożytnej ${ }^{9}$. Autor włożył wiele trudu w przygotowanie swego dzieła. Przestudiował dostępne mu opracowania niemieckie, archiwalia, podpatrywał warsztat niemieckich mistrzów i opublikował pracę... o antypolskiej wymowie. Fascynacja dorobkiem swoich poprzedników oraz bezkrytyczne odtwarzanie przekazów źródłowych sprawiło, że S. Wałęga ukazał wizerunek Torunia lat 1724-95 z punktu widzenia ówczesnej rady miejskiej, z typową dla niej niechęcią do Polaków i katolików Torunia.

Niefachowe podejście do materiału źródłowego wymuszało stosowanie literackiej narracji. Sprzyjało rozpamiętywaniu przeszłości, dowolności ocen, łączeniu faktów historycznych $z$ legendą miejscową, symboliką, fantazją itp. Prace historyków amatorów konceptualizowane były (jeżeli w ogóle były) wiedzą potoczną. Widoczne przy tym było podporządkowanie treści aktualnym nastrojom i ambicjom politycznym.

Największą wagę historycy amatorzy przywiązywali do wydarzeń politycznych. Z historii społecznej najchętniej prezentowali obrazy z życia lokalnych elit. Proces dziejowy traktowali jako produkt działalności jednostki. Najczęściej spotykaną praktyką było jednak poruszanie się w obrębie wszystkich możliwych tematów i przecenianie ich doniosłości. Widać to w książce ks. Aleksandra Bastrzykowskiego o dziejach parafii Jankowice Kościelne Sandomierskie ${ }^{10}$. Oddzielne rozdziały autor poświęcił w niej sprawom założenia parafii, historii i opisu miejscowego kościoła, plebanii, bractw, uposażenia kościoła, opisu szpitala, domu schronienia dla ubogich, ubiorów dawnych i obecnych, wykopalisk, emigracji przed- i powojennej. W dalszej części zamieścił oddzielny rozdział o roślinności stepowej w Sandomierskiem. Następnie powrócił do epizodów z życia św. Andrzeja Boboli i jego rodziny. Dalej przedstawiał postawy miejscowych dziedziców, działalność instytucji społecznych oraz teksty lokalnych piosenek ludowych.

9 S. Wałęga, Dzieje polityczne Torunia u schytku Rzeczypospolitej (1724-95), „Rocznik Towarzystwa Naukowego w Toruniu", r. 39, 1933, s. 1-392.

10 A. Bastrzykowski, Monografia historyczna parafii Jankowice Kościelne Sandomierskie, Warszawa 1929. 
Taki sposób myślenia o historiografii wynikał przede wszystkim z braku przygotowania naukowego autorów - miłośników przeszłości i „mniejszej ojczyzny". Jest jednocześnie obrazem zainteresowań historycznych lokalnych społeczności.

Inaczej rzecz się miała w przypadku osób utożsamiających się z nauką historyczną lub naukami pokrewnymi. Łączyło ich często wykształcenie historyczne oraz przekonanie, że przede wszystkim służą oni potrzebom naukowym, a historię regionalną czy lokalną uprawiają zgodnie $z$ ogólnymi wymaganiami historiografii.

W tej grupie badaczy dają się zauważyć dwie większe podgrupy. Pierwszą z nich tworzyli historycy przygotowani pod względem fachowym, lecz piszący w sposób tradycyjny. Łączyć ich można między innymi z powstałymi w latach 1918-39 próbami monografii takich regionów, jak: Śląsk, Wielkopolska, Pomorze. Najbardziej charakterystyczną cechą tej twórczości była względna poprawność warsztatowa. Historiografia ta mniejsze postępy poczyniła w zakresie realizacji zasady obiektywizmu, aczkolwiek wyrastała $\mathrm{w}$ znacznym stopniu $\mathrm{z}$ naukowej potrzeby przeciwstawienia się nacjonalistycznej historiografii niemieckiej, zacierającej istniejące świadectwa polskości na historycznych ziemiach zachodnich i północnych Rzeczypospolitej ${ }^{11}$. Wiązało się to ze sprawą emocjonalnego angażowania się autorów w przeszłość swej „mniejszej ojczyzny” oraz bieżące problemy odrodzonego państwa.

Podobne zjawisko pojawiło się na wschodnich rubieżach Rzeczypospolitej. Historyków regionalistów, działających na kresach wschodnich i zachodnich, moglibyśmy więc nazwać swego rodzaju "grupą zadaniową", wspierającą polskie interesy na tych terenach. Zastrzec jednak należy, że wprowadzanie do \zieł historyków fachowych aktualnych pierwiastków politycznych czy ideologicznych nie miało charakteru tak bezpośredniego, jak to było w przypadku amatorów. Autorzy ci dążyli z reguły do nadania swojej narracji pozorów neutralności. Swe ukryte cele realizowali częściej poprzez umiejętny dobór faktów, wartościowanie, stosowanie analogii itp.

Dążenie do "unaukowienia" historii regionalnej przez badaczy fachowych uwidacznia się najbardziej w sposobie ujmowania dziejów. Obok jednostek i ich czynów pojawiły się z czasem „masy społeczne”, będące równoprawnym elementem dziejotwórczym. Powszechną praktyką stało się wprowadzanie tzw. tła historycznego oraz dbałość o poprawność konstrukcji.

11 Por. np. B. Wysocka, Regionalizm Wielkopolski w II Rzeczypospolitej, Poznań 1981. 
Postęp dokonywał się więc stopniowo, aczkolwiek nie bez pewnych oporów.

Odmiennie rzecz się miała w przypadku prac (lub ich koncepcji) nowatorskich, publikowanych przez historyków profesjonalnych (często akademickich), stanowiących drugą podgrupę autorów utożsamiających się z zadaniami nauki. Za takie uważać można między innymi tzw. monografie wiejskie, powstałe w szkole Franciszka Bujaka, teorie Jana Rutkowskiego i niektóre prace wyrosłe na gruncie socjologii. Zmierzały one wyraźnie do wypracowania nowego modelu badań regionalnych.

Pierwsze nowoczesne monografie wsi zostały napisane na początku naszego stulecia przez F. Bujaka. Miały stanowić podstawę dla przyszłej, wszechstronnej monografii Galicji. Przyczyniły się do ukształtowania się w II Rzeczypospolitej nowego kierunku badań historyczno-regionalnych. Nowatorstwo F. Bujaka rozpoczęło się od nobilitacji źródeł, które w opinii historyków z katedr uniwersyteckich miały pozostać domeną badaczy lokalnych. Historyk lwowski bowiem oprócz materiałów urzędowych, takich jak księgi hipoteczne, metryki kościelne, akta spisów ludności, proponował także zapoznanie się z działalnością szkoły, urzędu gminnego, kościoła, instytucji kredytowych itp. Wskazywał także na zasadność zbadania oddziaływania starostwa, sądów, instytucji gospodarczych i kulturalnych z sąsiednich miejscowości, a także przeprowadzenia wywiadów $z$ ogółem mieszkańców na temat istniejących tam stosunków rodzinnych i majątkowych.

Żmiąa, Maszkienice, Limanowa i inne prace składające się na jego dorobek, mimo pewnych niedostatków metodologicznych, stały się w dwudziestoleciu międzywojennym wzorem pod względem metody badawczej dla licznego grona historyków społeczno-gospodarczych. Większość z nich została opublikowana w seriach wydawniczych, redagowanych przez F. Bujaka, zwłaszcza Badaniach do dziejów spotecznych i gospodarczych. Autorzy zawartych w nich publikacji opierali się głównie na dwóch metodach: monograficznej (w wersji socjograficznej i historycznej) oraz statystycznej.

W pierwszym wypadku mamy do czynienia $z$ rozwinięta i wzbogaconą adaptacją metody La Playa, utożsamianą z Francuską Szkołą Społeczną. Modyfikacje Bujakowskie polegały głównie na przesunięciu metody obserwacji $\mathrm{z}$ rodziny na zbiorowość terytorialną oraz dostosowaniu schematu badawczego do potrzeb historyków. Miało to służyć wykrywaniu określonych zjawisk typowych, do których dochodzi się poprzez zsumowanie badań jednostkowych. W pracach Bujaka daje się zauważyć pewna ewolucja praktyki badawczej, polegająca na systematycznym przechodzeniu od ujęć socjograficznych do koncepcji monografii opisowej. Zmodyfikowana koncepcja mono- 
grafii opierała się głównie na mikroanalizie wybranych zagadnień z historii społeczno-gospodarczej.

W naukowym nurcie historiografii regionalnej znalazła swe trwałe miejsce także metoda statystyczna. Stało się to również głównie za sprawą F. Bujaka, który przejął ją od profesora Uniwersytetu Jagiellońskiego Józefa Kleczyńskiego, uważającego - podobnie jak współczesny mu socjolog Stanisław Rychliński - że „statystyka [...] w coraz większym stopniu zapobiega brakom zwykłego opisu znamion zewnętrznych procesów, odbywających się w środowisku społecznym. Statystyka - pisał - zastępuje do pewnego stopnia ścisłe pomiary, dokonywane przy pomocy przyrządów laboratoryjnych w fizyce. [...] pozwala także na wybór ze zbyt licznej całości zjawisk, objętej zainteresowaniami badacza, przejawów reprezentacyjnych, które można lepiej zbadać [...]. Wreszcie, co najważniejsze, metoda statystyczna umożliwia kojarzenie cech wymiernych na płaszczyźnie zupełnie obiektywnej" ${ }^{12}$.

W przypadku F. Bujaka mamy do czynienia w tym względzie z postawą bardziej powściągliwą. Pełna afirmacja metody statystycznej występowała w zasadzie tylko w pierwszym okresie jego twórczości. Widać to wyraźnie w jego opisach socjograficznych, a zwłaszcza w Maszkienicach. Później wyczuwalne stają się wątpliwości, wynikające $z$ niepokoju o walory poznawcze tej metody oraz porównywalność analizy ilościowej i jakościowej.

W oparciu o interpretację danych statystycznych powstało szereg prac innych autorów, będących jej wizytówką. Na uwagę zasługują głównie tzw. pobujakowskie monografie wiejskie, pod względem konstrukcji nawiązujące do kwestionariusza $\dot{Z}$ miącej13. Osobną grupę prac stanowią opisy porównawcze dwóch (lub więcej) wsi, w których opisy socjograficzne zostały wzbogacone przez zastosowanie metody porównawczej ${ }^{14}$. Pod względem wartości ustępują one jednak swym pierwowzorom.

Postulaty modernizacji regionalistyki historycznej formułował też poznański uczony Jan Rutkowski we wczesnym okresie swej działalności badawczej - u progu odzyskania niepodległości przez Polskę. Później dokonał on przewartościowania swych poglądów. Na temat historii lokalnej wypo-

12 S. Rychliński, Badania środowiska spotecznego. Podstawowe zagadnienia metodologiczne, Warszawa 1932, s. 41-42.

13 Np. W. Staniewicz, Majtuzy Botondziszki, wieś powiatu lidzkiego. Studium spoteczne i gospodarcze, Wilno 1923; J. Fierich, Broniszów, wieś powiatu ropczyckiego, Ropczyce 1936.

14 F. Guściora, Trzy Kurzyny, wsie powiatu niskiego [Warszawa 1929]; W. Gortat, Góra Batdrzychowska i Byczyna. Opis porównawczy wsi na gruntach scalonych, wsi majacej szachownicę, Warszawa 1928. 
wiadał się kilkakrotnie, w trakcie konstruowania swego modelu historiografii wyjaśniającej i teoretycznej.

Najbardziej wyraziście wyraził swe stanowisko w recenzji pracy Romana Grodeckiego o książęcej własności trzebnickiej. Pochwalał w niej pomysł wykorzystania lokalnych źródeł archiwalnych do dwojakiego celu: zrozumienia ich indywidualnego, lokalnego znaczenia oraz oceny ich wartości ogólnej. „Jest to bardzo ważna zasada metodologiczna [...], która winna znaleźć zastosowanie przy wszystkich tego typu badaniach. Zasada ta jednak, stwierdzał dalej 28-letni wówczas Rutkowski, [...] musi być jednak do pewnego stopnia uzupełniona: nie można bowiem zapominać, że tylko punkt wy jścia badania ma być ściśle lokalny, jego cele muszą być zawsze ogólne i z tego punktu widzenia powinny być przedstawiane wyniki lokalnych badań; chodzić mianowicie musi o wyjaśnienie zagadnień ogólniejszych na podstawie materiału lokalnego. Zasada ta - pisał - powinna być ideą przewodnią całego badania" ${ }^{15}$. W recenzji tej pojawia się także postulat konceptualizowania temu podobnych badań elementami wiedzy ekonomicznej.

Nie sposób też pominąć wpływu na historię innych dyscyplin nauki. Prym w tej dziedzinie wiodła socjologia. Zaznaczył się on głównie w tzw. monografiach terytorialnych. Miały one bardzo szeroki zakres tematyczny, a ujmowane były pod kątem widzenia polityki społecznej. Tylko rozdział wstępny dotyczył problematyki historycznej, ale w wielu wypadkach te obszerne fragmenty mogłyby pretendować do rangi samodzielnych rozpraw.

Metodologiczne podstawy dla tego typu opracowań stworzyli S. Rychliński i S. Orsini-Rosenberg. Według ich założeń monografie terytorialne miały opierać się na metodzie La Playa i dwóch metodach amerykańskich: surveys i case studies. Podstawowymi narzędziami pracy miała być natomiast obserwacja, ankieta, wypowiedzi respondentów na piśmie i wywiad. W najciekawszej pracy Rychlińskiego znalazły się także wzory badań lokalnych. We wszystkich tych modelach elementy historii pojmowane były jako podłoże współczesnego kształtu stosunków społecznych, gospodarczych i kulturalnych.

$\mathrm{Na}$ jakość całej polskiej regionalistyki historycznej korzystnie oddziaływała dyskusja nad istotą i zadaniami badań nad „mniejszą ojczyzną". Na podstawie dostępnego materiału badawczego można stwierdzić, że opinie na ten temat były zazwyczaj ogłaszane przez historyków, którzy reprezen-

15 J. Topolski, O nowy model historii. Jan Rutkowski (1886-1949), Warszawa 1986, s. $65-66$. 
towali wyspecjalizowane działy historii, a dziejami regionalnymi zajmowali się raczej okazjonalnie. Ponieważ należeli oni do elity polskiego świata historycznego (lub świata nauk pokrewnych), to ich wypowiedzi miały charakter szczególnie miarodajny. Nierzadko stanowiły one punkt wyjścia do rozważań ogólniejszej natury. Przyjrzyjmy się najbardziej charakterystycznym wypowiedziom na ten temat oraz ich ewolucji.

Jeszcze staromodnie, czy wręcz archaicznie, brzmiał w pierwszych latach II Rzeczypospolitej głos historyka zamojskiego (później lwowskiego) Kazimierza Sochaniewicza. Snując refleksję na temat dziejów „mniejszej ojczyzny", twierdził on na przykład, że cokolwiek to będzie i gdziekolwiek, jeżeli jest tylko związane $z$ historią polską, powinno znaleźć się w jaźni narodowej i budzić takie uczucia, jakie budził św. Graal w sercach rycerzy okrągłego stołu; „niech będzie - pisał Sochaniewicz - przedmiotem czci i zapału takiego, jaki się budził w sercach krzyżowców na ziemi, po której stąpała stopa »Zbawiciela świata «" 16 .

W 1928 r. do dyskusji włączył się wybitny historyk warszawski, Marceli Handelsman. Z jego wypowiedzi, opublikowanej w „Roczniku Łódzkim”, dowiadujemy się, że „przez regionalizm rozumie się badanie, w pełni zakresu przeszłości i teraźniejszości, stosunków pewnej dzielnicy, okręgu czy miasta, oraz popularyzowanie wiedzy o tym wśród szerokiego ogółu" ${ }^{17}$. Konsekwencją tego działania powinno być - według Handelsmana - ukształtowanie się konstruktywnej świadomości regionalnej, dobrze służącej Polsce. Aczkolwiek w dalszej części artykułu Handelsman wskazywał na istniejące przy tym niebezpieczeństwo schematyzacji postępowania badawczego, nie odmawiał historii regionalnej potencjalnych atrybutów naukowych. Wyraźnie jednak rozgraniczał badania i popularyzację. Podobne rozumienie tej problematyki prezentowała znawczyni dziejów literatury, Stefania Skwarczyńska. Autorka ta w swych kónstatacjach nie posunęła się właściwie dalej. Poza zestawieniem katalogu trudności, jakie towarzyszą badaniom regionalnym, uzupełniła powyższy pogląd bardzo ogólnym stwierdzeniem, z którego wynika, że „regionalizm uderza w dwa przedmioty badania: Ziemię i człowieka” ${ }^{18}$. Dla badaczy tych ważniejszy był więc charakter przedmiotu badania niż zakres prowadzonych badań. Regionalistyka w ich przekonaniu obejmowała zarówno badania przeszłości miast jak i historycznych prowincji kraju.

16 K. Sochaniewicz, Kult przeszłości w wychowaniu narodowem, Zamość 1921, s. 13.

17 M. Handelsman, Zamiast programu badań, „Rocznik Łódzki”, t. 1, 1928, s. 11-14.

18 S. Skwarczyńska, Regionalizm a główne kierunki literatury, w: Prace polonistyczne, Łódź 1937, s. 8. 
Zapowiedzią nowego podejścia do historii regionalnej stał się głos ówczesnego docenta Uniwersytetu Warszawskiego, Stanisława Arnolda, znawcy wieków średnich i zarazem jednego z najbardziej konsekwentnych teoretyków i rzeczników regionalizmu w II Rzeczypospolitej. Na łamach „Ziemi” (swoistej trybuny polskich regionalistów) stwierdzał on, iż znaczenie pojęcia historii regionalnej wyznacza sam termin „region”, będący wytworem procesów geograficzno-historycznych, które należy badać w obrębie większych jednostek terytorialno-ludnościowych ${ }^{19}$. Badania nad miastami uznawał zaś raczej za domenę historii lokalnej.

Jednoznacznego rozróżnienia tych pojęć dokonał krakowski mediewista Karol Buczek. W referacie wygłoszonym na VI Powszechnym Zjeździe Historyków Polskich w Wilnie (1935 r.) poczynił zastrzeżenie co do monolitycznego rozumienia historii poszczególnych jednostek terytorialno-ludnościowych. Wyodrębnił przy tym jak gdyby dwa nurty regionalistyki: historię regionalną i lokalną. Nie definiował niestety tych pojęć ${ }^{20}$.

Interesujące światło na poziom teoretycznej refleksji nad historią regionalną rzuca zapomniany nieco artykuł Adama Próchnika, ogłoszony już u schyłku II Rzeczypospolitej ${ }^{21}$. Według tegoż historyka i działacza PPS historia regionalna i lokalna (podobnie jak K. Buczek dokonywał takiego rozróżnienia) to studia nad zagadnieniami historii „małych ojczyzn”. Moga one mieć charakter naukowy i popularyzatorski. Stanowią zwykle - w opinii autora - część większej całości (tj. są elementem historii ogólnej) lub posiadają samodzielny wymiar (czyli są składnikiem historii regionu). Wprawdzie każda zdobycz historiografii regionalnej (lokalnej) stanowi jednocześnie pewien wkład do dziejów narodowych (państwowych), jednakże kryterium klasyfikacji dla A. Próchnika stanowiła świadomość badacza, wyrażająca się w tym, „czy z punktu widzenia ogólnych potrzeb schodzimy na teren lokalny, czy też uprzytomniamy sobie odrębne, mające własne znaczenie, potrzeby historii regionalnej" 22.

Prace pierwszej grupy - zdaniem Próchnika - były na ogół przedmiotem badań wybitnych historyków, towarzystw naukowych, seminariów histo-

19 S. Arnold, Historia a regionalizm, „Ziemia”, r. 10, 1925, nr 1, s. 9.

20 Por. K. Buczek, Zagadnienie regionalizmu w nauczaniu historii $w$ szkole średniej, w: Pamiętnik VI Powszechnego Zjazdu Historyków w Wilnie. 17-20 września 1935 r., t. I: Referaty, Lwów 1935, s. 541-548.

21 A. Próchnik, Samorzqd a zagadnienie historii regionalnej, "Samorząd Miejski”, r. 18,1939 , nr 9 , s. $662-672$.

22 Ibidem, s. 662 . 
rycznych itp., miały one jednak często charakter przypadkowy i fragmentaryczny. Podejmowano na tym gruncie tylko te zagadnienia historii regionalnej i lokalnej, które charakteryzowały się ogólniejszymi odniesieniami. Prace regionalne wykonywane w centralnych ośrodkach naukowych $z$ racji tego, że były prowadzone przez najlepszych specjalistów i przy użyciu najlepszych metod, z zastosowaniem profesjonalnego aparatu naukowego, Próchnik oceniał najwyżej, ale tylko pod względem fachowości. Równocześnie jednak wyrażał przekonanie, że prace specjalistyczne gubią najistotniejsze wartości historii regionalnej, ściśle związanej z terenem danego regionu. „Historia - pisał - musi mieć swoje rumieńce, musi odtworzyć nie tylko kontury, ale również barwę przeszłości" ${ }^{23}$, tak charakterystyczną na przykład dla małych miast. Tłumaczył, że tak jak nie może być historii powszechnej bez uwzględnienia odrębności narodowych państw w niej uczestniczących, tak nie jest możliwa synteza dziejów Polski bez odwołania się do specyfiki, kolorytu, niepowtarzalnego klimatu poszczególnych regionów i ośrodków miejskich. Próchnik zapewniał, że tylko w terenie istnieje odpowiednia atmosfera do pielęgnowania takich studiów. Wskazywał jednocześnie na fakt, że podstawowa baza źródłowa w tym przypadku zazwyczaj znajduje się na miejscu. Łatwiej zatem skonfrontować ją ze źródłami centralnymi i ogólnymi niż odwrotnie.

Zarówno wymieniani, jak i inni historycy konkretyzowali swoje poglądy na temat historii regionalnej i lokalnej w wypowiedziach dotyczących jej funkcji politycznych oraz społecznych. Inspirowała ich do tego przede wszystkim nowa sytuacja społeczno-polityczna w kraju po 1918 r. oraz, co się z tym wiąże, nowe potrzeby państwa i społeczeństwa polskiego.

Przypomnijmy, że w XIX i na początku XX w. regionalizm był jedną $z$ dróg poznawania i przeżywania historii. Rozwój zainteresowań historycznych oraz towarzyszące im bariery polityczne, administracyjne i finansowe (rozdzielenie ziem polskich granicami państw zaborczych, utrudniony dostęp do źródeł, niechęć zaborców do polskiego ruchu naukowego, niedostatek środków materialnych na badania, zbyt mała ilość instytucji naukowych wspierających i koordynujących prowadzone prace) wymuszały zamykanie się wielu dziejopisarzy w tematyce regionalnej. Aczkolwiek w ten sposób powstawały dzieła o różnej wartości, niekwestionowanym faktem pozostaje dążność tych ludzi do pielęgnowania polskości, tradyc.ji narodowych, obyczajów, zespalania lokalnych społeczności wokół wspólnej historii itp., słowem 
walki o kulturę narodową. Prace te były wówczas przede wszystkim domeną inteligenc ji ${ }^{24}$.

Po I wojnie światowej sytuacja na tym polu radykalnie się zmieniła. Zniknęło szereg dotychczasowych ograniczeń i konieczności, regionalizm zyskał nowe bodźce. Świat historyczny dojrzał w nim szansę przyspieszenia zjednoczenia i rozwoju państwa w zakresie życia politycznego, społecznego, gospodarczego i kulturalnego, przekroczenia dawnych kordonów oraz dyslokacji ośrodków kultury polskiej.

Po 1918 r. zaczęto coraz częściej podnosić problem naukowych funkcji historii regionalnej i lokalnej. Nowe perspektywy przed regionalistyką otworzyła w głównej mierze potrzeba nowego, całościowego ujęcia dziejów Polski. Dziewiętnastowieczne opracowania tego typu, aczkolwiek liczne, nie mogły dłużej spełniać swej roli. Nowa synteza dziejów Polski nie mogła się jednak obejść bez zaktualizowanej wiedzy na temat dziejów poszczególnych regionów, subregionów, miast i wsi. Szczupłość kadry historyków zawodowych, skupionych wówczas głównie w ośrodkach akademickich, zmuszała do włączenia się do realizacji tychże zadań historyków regionalistów.

Sprzy jało temu przełamanie jeszcze na początku XX w. monopolu historii politycznej. Głównie za sprawą F. Bujaka i J. Rutkowskiego (a później ich uczniów) coraz większe uznanie zaczęły zdobywać oparte na naukowych podstawach badania z zakresu historii społecznej i gospodarczej. Jak słusznie zauważył Władysław Rusiński, „możliwości na odcinku dziejopisarstwa lokalnego i regionalnego wzrosły tym samym niepomiernie, liczba bowiem miejscowości posiadających na tyle atrakcyjny rodowód w sensie historii politycznej, aby mogły stać się przedmiotem osobnych badań, była ograniczona, natomiast każde nawet najmniejsze osiedle miało swoje »życie codzienne «, które mogło być śledzone nieraz z dość daleko sięgającą retrospekcją" 25.

Kolejnym czynnikiem stymulującym postęp i rozwój regionalistyki było wprzęgnięcie jej w służbę badań interdyscyplinarnych. Sprzyjała temu powolna decentralizacja polskiego życia naukowego oraz jeszcze wolniejszy (ale realny) wzrost kultury metodologicznej historyków regionalistów w okresie II Rzeczypospolitej. Poważny udział mieli w tym historycy zgrupowani wokół Polskiego Towarzystwa Historycznego oraz regionalnych towarzystw naukowych. Sprawy te również znajdowały odzwierciedlenie w wypowiedziach

24 Por. B. Gołębiowski, O ksztatcie wspótczesnego regionalizmu, „Profile” 1970, nr 3, s. 17.

25 W sprawie historii regionalnej, „Kwartalnik Historyczny”, r. 81, 1974, nr 3, s. 503. 
wielu badaczy. Największą wymowę mają opinie historyków uznanych, chętnie cytowanych $w$ czasopismach regionalnych i rozprawach wydawanych z dala od głównych ośrodków naukowych.

Cytowany powyżej A. Próchnik uważał, że z powodów praktycznych do badań nad dziejami miast i wsi należy włączyć nauczycieli i historyków amatorów (otoczonych opieką naukową ze strony profesjonalistów), gdyż tylko ci, ze względu na znajomość terenu, są w stanie oddać jego swoisty koloryt dziejowy. Taka organizacja pracy historycznej była dla niego także skuteczną drogą do podniesienia prestiżu kulturalnego prowincji i pogłębienia świadomości obywatelskiej. W tym względzie Próchnika można uznać za. reprezentanta, tej grupy historyków, która sądziła, iż naukowe aspekty historii regionalnej powinny korespondować z walorami społecznymi.

Pogląd taki reprezentował niemal przez cały okres swej działalności naukowej F. Bujak. Uczony ten zasadności pracy naukowej na prowincji upatrywał w mnogości historycznych ośrodków kulturalnych na ziemiach polskich oraz rozproszonemu (ziemiańskiemu) charakterowi naszej kultury w przeszłości. „Jest zatem co badać” - pisał w jednym ze swych artykułów ${ }^{26}$. Historyk lwowski badaczy dziejów małych miast traktował w sposób raczej pobłażliwy. Uważał, że „naukę uprawiać może każdy, jeżeli traktuje to jako hobby" 27. Historycy regionalni, dla lepszej organizacji swych ba,dań, powinni - według Bujaka - zrzeszać się w kółka naukowe oraz tworzyć muzea regionalne jako swój warsztat pracy. Przydałoby to zatem regionalistyce pewną funkcję organizatorską i inspiratorską. Szczegółowe wyniki badań lokalnych badaczy mogły posłużyć - jak sądził - do przyszłej syntezy dziejów społeczno-gospodarczych kraju.

Analogiczny stosunek do historyków „mniejszej ojczyzny” wyrażał znawca dziejów polskich powstań narodowych - Wacław Tokarz. Przedstawiciel warszawskiego środowiska historycznego nie zagłębiał się zbytnio w teoretyczne problemy historii regionalnej. Głosił kult faktu historycznego, wysoko sobie cenił nawet wycinkowe ustalenia regionalistów, dotyczące zwłaszcza dziejów małych, nie badanych dotychczas, miast oraz ruchów niepodległościowych w poszczególnych prowincjach. Upatrywał w nich drogi do pełnej syntezy w ramach poszczególnych dziedzin nauki historycznej28.

26 F. Bujak, Praca naukowa na prowincji. Wstęp ogólny,-„Nauka Polska”, t. 4, 1923, s. $81-114$.

27 Ibidem, s. 86.

28 Por. W. Tokarz, Stan i dezyderaty badań nad historia wojny polsko-rosyjskiej 1830-1831, w: Pamiętnik IV Powszechnego Zjazdu Historyków Polskich w Poznaniu 6-8 grudnia 1925 r., t. I: Referaty. Sekcja VI, Lwów 1925, s. 1-10. 
W podobnym duchu wypowiadali się też inni historycy, tacy jak: Łucja Charewiczowa, Józef Kucharzewski, Aleksander Patkowski i inni.

Postulowali oni, by do badań małych miast i wsi włączyły się szeroko środowiska oświatowe. Zaczęto nawet konstruować proste kwestionariusze badawcze, z którymi ruszaliby w teren domorośli badacze. Alicja Hłasko-Pawlicowa na przykład proponowała zaopatrzenie początku jących historyków w odpowiedni arkusz, w którym zaznaczaliby oni:

- „czy w danej miejscowości są ruiny zamku, kopce, kurhany, grodziska, pola bitew i co ludzie o nich opowiadają?

- czy przetrwała pamięć o jakimś bohaterze miejscowym?

- jakie dawne napisy pozostały na pomnikach, płytach grobowych i gmachach?

- jakie narzędzia pracy, naczynia i meble wzbudzają zdziwienie kształtem lub sposobem użycia?

- czy w danej okolicy są jakieś niezwykłe sposoby liczenia i mierzenia" itd. ${ }^{29}$

Uważano, że zebrany w ten sposób materiał mógłby zacząć swoje naukowe życie pod postacią kroniki szkolnej, miejskiej lub gminnej. Wyrażano przekonanie, że poprawnie prowadzona kronika może stać się „jakby podręcznikiem nauki o swojszczyźnie, lepszym od niejednej monografii" 30. Myśl tę podjęła prasa dla nauczycieli, publiku jąc wiele propozycji odnośnie sposobów dokonywania w niej zapisów, które powinny głównie uwzględniać tzw. tło lokalne, a w tym:

1) „zewnętrzne stosunki miejscowości, przypuszczalne założenie, wielkość obszaru gminnego, lasy, drogi, ilość budynków, stare sadyby z napisami, zdjęcia (stare i nowe), publiczne budowle, kulturalne prace, zabytki, nieszczęścia, ciężkie czasy,

2) ludność, jej stan liczebny, język i gwarę, religię, ważne rody, emigrację, charakterystyczne właściwości mieszkańców, zwyczaje, obyczaje, życie towarzyskie, uroczystości ludowe, podania,

3) obejście gminy, nazwy rzek, gór i lasów, gwarowe nazwy pól, wykopaliska, zapiski historyczne" ${ }^{31}$.

29 A. Hłasko-Pawlicowa, Wartości dydaktyczne i naukowe szkolnych wycieczek historycznych, „Wiadomości Historyczno-Dydaktyczne”, r. 2, 1934, z. 1, s. 69.

30 S. Gawroński, Co należy zapisywać w "Kronice szkolnej”?, „Przyjaciel Szkoły”, r. 9,1930 , nr 7 , s. $284-285$.

31 Ibidem, s. 285. 
Regionalizm historyczny miał oczywiście także swoich oponentów. Do nich należał przede wszystkim poznański uczony J. Rutkowski. Uważał on, że „sposób jak i badania regionalne u nas prowadzone - nastręcza sporo wątpliwości co do ich wartości dla ogólnego rozwoju nauki historycznej" ${ }^{32}$. $\mathrm{Na}$ karb braku w Polsce fachowej krytyki zapisał fakt powszechnego przeceniania prac o charakterze lokalnym. „Najbardziej jaskrawo uwydatnia się [to] - podkreślał - w monografiach miejscowości, gdzie jeden autor, który częstokroć bardzo słabo panuje nad samą metodą historyczną, podejmuje się opracowania zagadnień ze wszystkich działów kultury. Wybór faktów z materiału źródłowego jest wówczas zazwyczaj zupełnie przypadkowy, mało wartościowe szczegóły dokładnie opisywane, rzeczy wielkiej wagi częstokroć zupełnie omijane. Dobrze, jeżeli poszczególne ugrupowane są w sposób umożliwiający szybkie odszukanie wiadomości, dotyczących pewnej kategorii zjawisk; w literaturze naszej mamy szereg monografii miejscowości, w których na każdej niemal karcie znaleźć można wiadomości ze wszystkich niemal dziedzin życia" 33 .

Sytuacja taka - zdaniem Rutkowskiego - wynikła z błędu w myśleniu, że sama znajomość metody historycznej była tożsama z całkowitym przygotowaniem do pracy we wszystkich dziedzinach historii. Uważał, że od autorów syntez regionalnych i lokalnych należy wymagać przygotowania z dziedziny socjologii, ekonomii i innych dyscyplin wiedzy. W związku z tym apelowal, by badacze regionalni (a zwłaszcza historycy miast) nie rozpraszali swoich sił na próby u jęć monograficznych. Spełnienie ambicji twórczych tej grupy historyków widział w analitycznych opracowaniach poszczególnych zagadnień w ramach ich rzeczowej klasyfikacji, inwentaryzowaniu, opisywaniu i publikowaniu źródeł do dziejów miejscowości, powiatów itd. Tylko taki wymiar regionalnej twórczości historycznej mógłby - zdaniem poznańskiego uczonego - przynieść realne korzyści. Pozwoliłoby to na dotarcie historyków zawodowych do wielu rozproszonych i nieznanych dotychczas źródeł, a jednocześnie na podniesienie poziomu kultury historycznej mieszkańców danego terytorium.

Regionalizm historyczny bywał krytykowany także $z$ innych powodów. Przypisywano mu znamiona ciasnego prowincjonalizmu, zaściankowości, źle pojętego lokalnego patriotyzmu czy nawet skłonność do séparatyzmu dzielnicowego. Zarzuty te rzadko jednak miały jakiś związek z nauką.

32 J. Rutkowski, O zadaniach pracy naukowej na prowincji w zakresie historii, „Nauka Polska", t. 4, 1923, s. 232-236.

33 Ibidem, s. 234. 
Niezależnie od słów krytyki badania historyczno-regionalne cieszyły się w II Rzeczy pospolitej dużą popularnością, przyczyniając się do rozwoju nauki historycznej. Dość powiedzieć, że w latach 1918-39 powstało ok. 31 tys. publikacji historycznych, różnej wartości, z tego ok. 4100 o charakterze regionalnym i lokalnym, co stanowiło ok. $13 \%$ całości ówczesnej "produkcji” historiograficznej. Nastąpiła decentralizacja badań naukowych, możliwa do prześledzenia chociażby na mapie towarzystw i instytucji naukowych tego okresu. Na niwie społecznej zaowocowało to powstaniem nowej świadomości regionalnej, zaznaczającej się przywiązaniem do „mniejszej ojczyzny” i owocującej w dalszej perspektywie awansem cywilizacyjnym prowincji. 